\title{
NEW SPECIES OF SCARABAFIDAE (COLEOPTERA) FROII PUERTO RICO AND THE VIRGIN ISLANDS
}

\author{
By Edward A. Chapin, \\ Curator, Division of Insects, U.S. National Museum. $\left({ }^{1}\right)$
}

As it will probably be some considerable time before a projected revision of the Puerto Rican and Virgin Island species of Scarabaeidae can appear, it seems desirable to establish names for certain new species which have come to my attention. I am indebted to Dr. Stuart T. Danforth, Mr. R. G. Oakley and to the American Museum of Natural History for the gift or loan of the material described below.

\section{Canthochilum hispidum, new species}

Piceous, legs dark eastaneous, antennae and mouth parts paler. Entire dorsal surface set with very short, eapitate hairs, most densely placed on pronotum and along the elytral striae. Head nearly smooth, minutely punctured except for two oval patches of coarser punctures on the vertex, one patch on either side of the slightly elevated median line. Eyes large, transverse diameter of eye equal to one-fifth distance between eyes. Clypeus quadridentate with middle pair of teeth acute and slightly recurved, genal angles also slightly prominent, each tooth or prominence with a tuft of setae above and below. Pronotum transverse, almost twice as wide as long, basal margin very broadly curved, sides parallel to apical fifth where they turn suddenly toward the median line, anterior angles distinct, posterior angles wanting, underside deeply excavated in anterior third for reception of anterior femora, excavation bounded by a strong carina. Surface strongly shagreened, densely and moderately coarsely punctured. Elytra more shining, less convex than pronotum, very finely striate, seventh stria bounded almost to apex by the strong lateral carina which is broadly interrupted just before its extremity, third interspace with a strong, blunt, subapical spine. Eight striae composed of large punctures and located on the inflexed portion. along a second carina. Under surface smooth, without setae, sternites crowded along median line, pygidium subtriangular, margin strongly beaded. Anterior femora strong, not alate, middle femora small and slender, tarsi of anterior legs feeble, strongly compressed, those of other legs well developed, not noticeably compressed, heavily clothed with pale pubescence. Claws minute.

Male: Pronotum strongly gibbous, anterior tibia slender, somewhat bent and enlarged in apical fourth, with three lateral teeth, of which the basal is a little remote from the others and with a single ventral tooth near insertion of tarsus; posterior femora broadly expanded in middle portion.

(1) Published with permission of the Secretary of the Smithsonian Institution. 
Female: Pronotum moderately convex, anterior tibia moderately broad, with three lateral teeth situated in the apical third but without a ventral tooth.

Length: $5.5-6.2 \mathrm{~mm}$.

Type locality: Villalba, Puerto Rico.

Type and twelve paratypes: U. S. Nat. Mus. Cat. No. 51079.

Material examined: Eight males and five females from the Insular Government Finca at Villalba, collected Sept. 7, 1934 by Mr. R. G. Oakley.

Because of the vestiture of capitate hairs, all specimens seen of this species have been almost completely covered with a layer of dirt, most difficult to remove.

\section{Canthochilum andyi, new species}

Piceous to deep black, anterior margin of head and legs castaneous, antemnae and mouth parts paler. Resembles $C$. histeroides Harold but larger and with more strongly punctured elytral striae. Head almost smooth, most finely shagreened and with a patch of minute punctures on vertex between eyes. Clypeus quadridentate, the middle teeth more slender than the lateral, almost equidistantly spaced, genal angles slightly prominent, each tooth or prominence with hair tufts above and below. Eyes large, nearly divided by canthus. Pronotum transverse, visibly shagreened only at sides, not visibly punctured except under high magnification; basal margin very broadly rounded, sides parallel to apical fourth, thence sharply convergent to the obtuse anterior angles. Under side excavated in anterior third for reception of femora, excavation bounded posteriorly by carina. Elytra distinctly shagreened, striae well defined and moderately coarsely punctured, the punctures larger toward apical extremity. Seventh stria bounded by lateral carina which ends near apical fourth. Eight stria on inflexed portion and bounded by a carina which reaches almost to extreme apex of suture. Under parts and pygidium as in preceding species. Anterior femora thickened, anterior tibiae coarsely denticulate in addition to the usual three teeth.

Male: Pronotum somewhat gibbous, posterior femora broadly expanded in middle portion, anterior tibiae rather slender, the teeth moderately long and acute in fresh specimens, middle tibiae somewhat, posterior tibiae strongly, arcuate and gradually widened to apices.

Female: Pronotum not more convex than is usual, posterior femora not expanded, anterior tibia moderately broad, middle and posterior tibiae feebly arcuate and gradually widened to apices.

Length: $5-5.5 \mathrm{~mm}$.

Type locality: Matrullas, Puerto Rico.

Type and fifteen paratypes: U. S. Nat. Mus. Cat. No. 51080.

Material examined: Four males and twelve females from the Insular Government Finca at Matrullas Dam, near Orocovis, collected October 8, 1934 by Mr. R. G. Oakley. 


\section{Cyclocephala danforthi, new species}

Similar to Cyclocephala vincentiae Arrow in size and form. Testaceous, vertex piceous. Lower portion of frons and upper portion of clypeus moderately strongly and confluently punctured, lower portion of clypeus shining, clypeal margin feebly reflexed laterally, strongly so at the broadly rounded anterior margin. Antenal club of male very large, one third longer than distance between eyes. Pronotum with lateral margins subangulate at middle, sparseiy, and rather finely punctured. Scutellum very finely punctured at sides. Elytra with faintly indicated rows of punctures, the interspaces rather coarsely and sparsely punctured. Underparts slightly darker in color than upper, metasternum finely and closely punctured except at middle and on either side adjacent to hind coxae. Pygidium closely and finely granulate. Anterior tibiae tridentate, anterior tarsus of male short and stout, the third to fifth segments with striated areas on inner faces, fifth segment strongly inflated. Claws of anterior tarsus, very dissimilar in size, the larger broad and bifurcated in apical fourth, the rami dissimilar and widely divergent.

Length: $11 \mathrm{~mm}$.

Type locality: Great Bay, St. Martin, Virgin Islands.

Type: U. S. Nat. Mus. Cat. No. 51081; paratype in collection of Dr. S. T. Danforth.

Material examined: Two males from the above-mentioned locality colected Dec. 23, 1927, by Dr. S. T. Danforth.

\section{Epiphileurus puertoricensis, new species}

Near Epiphileurus cribratus Chevrolat but larger with less coarsely punctured pronotum and with quite different aedeagus. Head sparsely set with ill defined punctures, frons of male with a deep, circular pit which is puncture-free, of female slightly concave with a few coarse punctures. Apex of clypeus acute and reflexed, horns over the antennal insertion short, stout and obtuse. Pronotum with an ill-defined median groove which bears a few medium-sized ocellate punctures, rest of surface sparsely punctured, the punctures coarse on disc either side of median groove and very fine along the lateral and basal margin. Anterior angles acute and produced, posterior angles rounded. Elytra with rows of ocellate punctures, the rows somewhat paired, so that the sutural, second, fourth and sixih interspaces are more elevated than the first, third and fifth. Lateral portions of underside with large, ocellate punctures. Pygidium coarsely and rather sparsely punctured, strongly convex in male, less so in female. Anterior tibia tridentate, the teeth slender and acute. Anterior tarsi similar in the sexes.

Length: $15-16 \mathrm{~mm}$.

Type locality: Villalba, Puerto Rico; also from Barranquitas, P. R.

Type and nine paratypes: U. S. Nat. Mus. Cat. No. 51082.

Material examined: One male from the Insular Government, Finca, Villalba, collected Oct. 26, 1933, by Mr. R. G. Oakley; seven 
males and one female from same locality, June 29, 1934, Oakley; one male and three females from Barranquitas, collected Dec. 1930 by Mr. R. Colón and received for study from Dr. S. T. Danforth and American Museum of Natural History. Two paratypes, male and female, returned to Dr. Danforth, one female paratype returned to the American Museum.

\section{Phyllophaga yunqueana, new species}

Large, subdepressed, color yellow brown with head, pronotum and elytra rich reddish castaneous with a dense bluish-white bloom conspicuous only in eertain lights. Legs pale with tibiae and tarsi slightly darker. Head moderately coarsely, evenly but sparsely punctured, clypeo-frontal suture deep, clypeus slightly tumid, a little more sparsely punctured than frons, margin gradually reflexed, median indentation broad and shallow. Antenna nine-segmented, club shorter than stem. Pronotum with sides subangulate at middle, anterior angles not at all produced, basal angles rounded, lateral marginal bead broken at intervals, a long hair arising from each break. Elytra with sutural margin slightly tumid, apices of suture minutely mucronate, discal costae obsolete, punctures similar in size to, but more densely placed than those on pronotum. Epipleura very narrow except at base. Pygidium strongly convex in male, coarsely and subconfluently punctured. Underparts rather densely and finely punctured at sides, sparsely so at middle. Anterior tibia strongly tridentate in both sexes, the upper tooth somewhat remote from middle. Tarsi moderately long, posterior tibia slender, hardly expanded at apex, calcaria slender, the longer noticeably longer than the first tarsal segment. Claws strongly curved, the median tooth strong.

\section{Length: $23 \mathrm{~mm}$.}

Type locality: El Yunque Mt., Luquillo Range, Puerto Rico.

Type: U. S. Nat. Mus. Cat. No. 51083. Paratype in American Museum of Natural History.

Material examined: A male collected February 1900 by Dr. Leonhard Stejneger; a female collected Oct. 4, 1919, in the collection of the American Museum of Natural History.

\section{Phyllophaga discalis, new species}

Below medium size, yellowish to reddish brown, elytra and flanks of pronotum reddish brown, head and dise of pronotum deep eastaneous. Head with frons coarsely and confluently punctured, with a deeply impressed median line, elypeo-frontal suture deep, elypeus with punctures similar to those on frons, margin narrowly reflexed, median indentation broad, shallow and not angulate. Antennae nine-segmented, club shorter than stem. Pronotum notably transverse and convex, sides subangulate at middle, anterior angles obtuse, not produced, basal angles rounded, lateral marginal bead broken in a few places and with long hairs at breaks. Elytra with sutural margin slightly tumid, apices of sutural bead minutely mucronate, diseal costae absent, rather more finely and densely punctured than pronotum. Epipleura very narrow. Pygidium only slightly convex in male, sparsely and not coarsely punctured. 
Under parts finely and densely punctured at sides, very sparsely so at middle. Anterior tibia tridentate in both sexes, the basal tooth a little remote from middle. Posterior tibia slender, not greatly expanded apically. Calcaria of posterior tibia narrow, the longer half again as long as the first tarsal segment. Tarsi moderately long, claws not strongly curved, tooth stout, situated a little beyond middle.

Length: $13-15 \mathrm{~mm}$.

Type locality: Yauco, Puerto Rico.

Type and paratypes: U. S. Nat. Mus. Cat. No. 51084.

Material examined: A male from Natalie Finca, in the mountains north of Yauco, Aug. 9, 1934, collected in the ground by Mr. R. G. Oakley; one male and one female from Añasco, P. R., Oct. 16, 1930, by Mr. J. A. Zalduondo.

The aedeagus of this species departs radically from the usual type found among the West Indian species. It is elongate tubular, with the apical margin somewhat modified and bears a striking resemblance to the type commonly found among the species of the Philippines. I have checked the specimens against our entire Asiatic series without success. The similarity may be due to convergent evolution or it may be that at some time Asiatic cane has been introduced into the island. 